\title{
Enzymes of importance to rhizosphere processes
}

\author{
L. Gianfreda ${ }^{1 *}$ \\ ${ }^{1}$ Dipartimento di Agraria - Università di Napoli Federico II, Naples, Italy *Corresponding author: liliana. \\ gianfreda@unina.it
}

\begin{abstract}
All processes and functions taking place in the rhizosphere are dominated by the activities of plant roots, rhizosphere microorganisms and root-microorganism interactions, and enzymes are recognized as main actors of all activities occurring in rhizosphere environments. Rhizosphere enzymes have, in general, a higher activity than those operating in bulk soil, as the rhizosphere soil is richer in organic C substrates. Enzymes, produced and released by both roots and microorganisms concur to altering the availability of nutrients in the rhizosphere, being implied in the hydrolysis of C-substrates and organic forms of nutrients such as $\mathrm{N}, \mathrm{P}$ and $\mathrm{S}$.

The production and activity of rhizosphere enzymes is controlled by several factors, in turn depending on soil-plant-microorganism interactions. In general, higher activity of rhizosphere enzymes can be interpreted as a greater functional diversity of the microbial community. An interesting aspect is their involvement in the possible removal of both inorganic and organic pollutants from the terrestrial food chain.

The lack of satisfying methodologies for measuring the location and activity of rhizosphere enzymes has often hampered a clear knowledge of their properties and functions. Sophisticated technologies, now available, will be helpful to reveal the origins, locations and activities of enzymes in rhizosphere.

The main scope of the present paper is to cover briefly general and specific concepts about rhizosphere enzymes and their role in soil processes. Examples chosen among those published recently, supporting and confirming properties, features, and functions of rhizosphere enzymes will be illustrated.
\end{abstract}

Keywords: Rhizosphere, enzymes, microorganisms, priming effect, root exudates

\section{Introduction}

Rhizosphere is a peculiar soil microenvironment where soil properties, plant-roots and microorganisms characteristics and activities interact to each other in a coordinated manner (Figure 1). All biological functions of plant roots such as uptake, respiration and exudation have their effects in the rhizosphere, by modifying biogeochemical parameters of soil (i.e. nutrient concentrations, pollutants, complexing or chelating compound concentrations, $\mathrm{pH}$ and redox potential, partial pressures of $\mathrm{O}_{2}$ and $\mathrm{CO}_{2}$, etc.). The stimulation of microorganisms by root exudates may result in the alteration of such biogeochemical properties and in turn of a large number of reactions at the soil solid/soil solution interface (Hinsinger et al., 2006). 


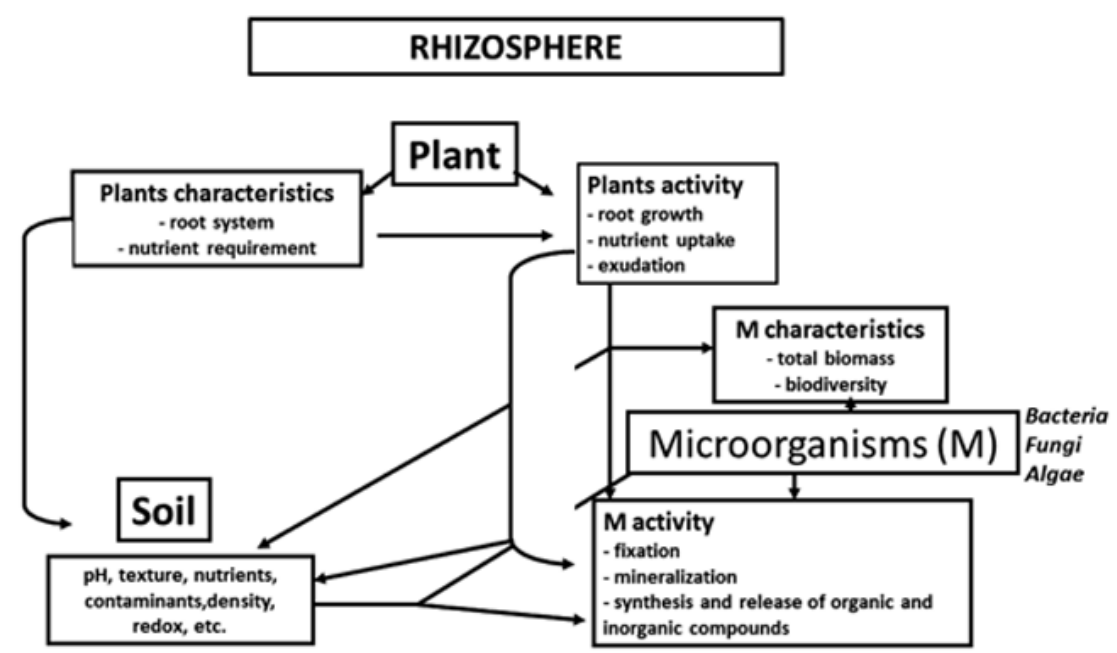

Figure 1. Description of rhizosphere and interactions occurring in it

Rhizosphere has been defined in several ways, all to underline the peculiar activities occurring in it. Hinsinger et al., (2008) called rhizosphere the "bio-influenced zone", i.e. the portion of the environment with which an organism interacts. Rhizosphere can also be considered as "a hot spot of activity" within soils and the "bottle neck" not only of the supply of vital elements to sustain ecosystem productivity and integrity and food security but also of the contamination of the terrestrial food chain by inorganic and organic pollutants to endanger human and animal health.

According to Raaijmakers et al. (2009), the rhizosphere may "harbor" microorganisms that can have not only beneficial but also deleterious effects on the plant. Pathogenic fungi, oomycetes, bacteria and nematodes can all exert adverse effects on plant growth and health, whereas nitrogen-fixing bacteria, endo- and ectomycorrhizal fungi and plant-growthpromoting bacteria (PGPR) and fungi are beneficial to plants. These two groups of microorganisms, adapted to survive in the rhizosphere, interact to each other and influence consequently pathogen infection. Raaijmakers et al. (2009) reviewed in detail the complex activity, dynamics and mechanisms of tripartite interactions between beneficial microorganisms, pathogens and plants as well as their response to agricultural practices.

In the rhizosphere, all organism physiological activities will result in changes of soil parameters and processes that determine nutrients availability. This latter will depend on how much each organism is capable to alter it in his 'bio-influenced zone'. In addition, nutrients bioavailability varies from one species or even from one genotype to another within a single species, depending on plant ability to alter rhizosphere processes and properties.

Another major process that can concur to altering the availability of nutrients in the rhizosphere is the release by roots and microorganisms of enzymes implied in the hydrolysis of organic forms of nutrients such as N, P and S. Their activity, regulation and 
production influence the development, composition and activity of rhizosphere microbial population and allow microorganisms to utilize preferentially the most suitable substrate for their growth. Therefore, the production and activity of rhizosphere microbial enzymes largely determines the state of health of plants.

The scope of the paper is to provide a brief overview of findings dealing with rhizosphere enzymes. The main factors affecting rhizosphere enzymes production and activity will be examined. A special emphasis will be devoted to interactions between microorganisms (including those genetically modified) and rhizosphere enzymes.

\section{Rhizosphere enzymes}

Many findings are available in literature on the allocation of enzyme activities in bulk and rhizosphere soils (Naseby and Lynch, 2002; Marinari et al., 2014). As plants takeup their nutrients through the rhizosphere, the inhabitant microbial community and its activity and function have a high significance for plant growth. Therefore, a great interest has been dedicated to: a) the accumulation of enzymes at interfaces between soil and plant roots; b) the participation of enzymes originating from proteins produced by plant roots and discharged in their surrounding rhizosphere soil; c) the effect of plant species composition and root type; d) the contribution of root mycorrhization on enzyme activities of rhizosphere soil (see Gianfreda and Ruggiero, 2006; Egamberdieva et al., 2011; Marinari et al., 2014). This interest is well documented by the doubling of the percentage of articles between years 2000-2013 with both keywords "soil enzymes" and "rhizosphere" on total articles with only "soil enzymes" as keyword (Marinari et al., 2014).
Enzyme activities of rhizosphere soils are generally higher than those of the bulk soil are. The higher enzyme activity of the rhizosphere depends not only on the stimulation of root-associated microbial activity by rhizodeposition but also on the release of enzymes by roots or by lysis of root cells. These enzymes are usually wall-associated enzymes and catalyze the formation of products, which are up-taken by plant roots or rhizosphere microorganisms (Gramss et al., 1999; Chroma et al., 2002; Harvey et al., 2002). Therefore, the enzyme activities at plant-soil interface may reflect improvement of the highly integrated microorganism-plant associations (symbiotic and plant growth promoting rhizobacteria) and control of plant pathogens and pests. It can be claimed that the enzyme activity profile of rhizosphere is a footprint of plant-microorganism interactions. Moreover, as well established by Dick (1994, 1997), soil enzyme activities (including rhizosphere ones) can be useful indexes of changes occurring in the microbial functioning in soil, as affected by various and different factors.

\subsection{Classes of rhizosphere enzymes}

Rhizosphere enzymes are classified in two main categories:

Enzymes, cytosolic in origin, but in association with cell debris, serving more likely as a ready source of carbon, nitrogen and reducing equivalents for the growth of microbial communities

Extracellular enzymes deliberately secreted by plant roots or microbes to the external environment. They either serve a protective function (oxidoreductases) and oxidize extracellular toxic soluble phenolic metabolites to insoluble polymerized products or have a degradative function (hydrolases and oxidoreductases) and hydrolyze or oxidize polymeric substrates such as lignin, humic acids or phenols for 
metabolic purposes. Since oxidoreductases show an apparent lack of substrate specificity, they are able to transform organic xenobiotics as well and this property has prompted efforts to exploit these enzymes for bioremediation purposes.

Phosphatases are typically more abundant in the rhizosphere and have been, likely, the most studied rhizosphere enzymes. As better explained below, further insights in the distribution of microbial- and root-derived phosphatase activities were provided by Spohn et al.(2013) and Spohn and Kuzyakov (2013, 2014) in their studies with the new technique soil zymography.

A strict correlation exists between phosphatases, originating from plant roots, and phosphorus nutrition of plants, particularly in rhizosphere soils of mycorrhiza-colonized plants (Gianfreda and Ruggiero, 2006 and references therein).

In natural and mined soil, Kumar et al. (2011) demonstrated that both acid and alkaline phosphatase activities had good relationships with inorganic P fractions and their activity varied with mycorrhizal association.

In their recent study, Maseko and Dakora (2013) assayed acid and alkaline phosphatases in rhizosphere and bulk soils of legumes, $\mathrm{N}_{2}$-fixing, mychorrizal, cluster-root forming plants (Cyclopia genistoides, $C$. subternata, Aspalathus caledonensis, A. Aspalathoides) and of a non-legume, non- $\mathrm{N}_{2}$-fixing plant (Mimetes cucullatus). Available inorganic (Pi) and organic (Po) phosphorous in rhizosphere soils as well as $\mathrm{P}$ in plant shoots were also determined. The enzymatic activity was in the order $C$. genistoides $>$ A. caledonensis $>A$. aspalathoides $>$ Mimetes cucullatus. Moreover, Pi level closely mirrored rhizosphere enzyme activity, non for A. caledonensis, which had high enzyme activity but low rhizosphere Pi level. Shoot P level closely mirrored rhizosphere $\mathrm{Pi}$ concentration of C. genistoides, A. aspalathoides and M. cucullatus, but not A. caledonensis. The peculiar behavior of A. caledonensis, that showed the second highest $\mathrm{P}$ enzyme activity, the lowest rhizosphere Pi and a greater concentration of $\mathrm{P}$ in shoots, suggests that rapid uptake of inorganic $\mathrm{P}$ occurred in A. caledonensis roots. As also observed for other plant species and genotypes, it could be inherently related to a greater $\mathrm{P}$ demand by A. caledonensis compared to the other co-occurring species such as A. aspalathoides and $C$. genistoides. Evidently "The intensity of acid phosphatase enzyme exudation is strongly influenced by the P demand of the plant species" (Maseko and Dakora, 2013).

George et al. (2002, 2008) already provided evidence on the relationship between $\mathrm{P}$ and phosphatase activities. Studies performed on agroforestry species showed that phosphatase activities actively increased in the rhizosphere of agroforestry species, either directly by secretion or indirectly by stimulation of microbial activity and/or depletion of Pi (George et al., 2002). Moreover, investigations were carried out to evaluate whether genotypic variation in rootassociated phosphatase activities in wheat could affect its ability to acquire phosphorus (P). Activities of root-associated phosphatase of plants against different organic P substrates and of representative genotypes were measured in both agar culture and in soils with differing organic $P$ contents. Relationships were found between differences in the activities of both root-associated and exuded phosphatases and the P content of plants (George et al., 2008).

Obviously, rhizosphere contains other enzymes in addition to phosphatases. In the rhizosphere of Citrus unshiu, positive correlations were found between the spatial distribution of total and easily extractable glomalin-related soil protein (GRSP), root mycorrhization, soil water-stable aggregates, water-extractable or hydrolysable carbohydrates and $\beta$-glucosidase (Wu et al., 2012). By contrast, negative correlations were found with protease. 
In a boreal fire chronosequence in Alaska, Gartner et al.(2012) correlated the enzyme activities of extracellular C-, P- and N-targeting enzymes with mycorrhizospheres of arbuscular mycorrhizal, ectomycorrhizal, dual-colonized (arbuscular and ectomycorrhizal), and ericoid mycorrhizal plants. In particular, $\mathrm{C}$-targeting $\beta$-glucosidase and peroxidase were lower in arbuscular mycorrhizospheres and ericoid mycorrhizospheres, respectively, than in bulk soil. Moreover, types of mycorrhizospheres influenced the activity of extracellular enzymes. For instance, the activity of $\mathrm{N}$-targeting leucine aminopeptidase was the highest in arbuscular mycorrhizospheres, followed by ericoid and ectomycorrhizal/dual-colonized mycorrhizospheres, whereas $\beta$-1,4-glucosidase had an opposite behavior. Authors concluded, "The community composition of mycorrhizal host plants might mediate enzymatic activity in boreal soils" (Gardner et al., 2012).

\section{Factors affecting production and activity of rhizosphere enzymes}

The activity and production of rhizosphere enzymes is affecting by several factors such as root exudates, atmospheric $\mathrm{CO}_{2}$, plant growth, soil management, temperature and aridity, salinity, plant-microorganism interactions, contaminants. Each of these factors will be briefly examined in the following gparagraphs.

\subsection{Root exudates}

Root exudates are usually C-rich or easily degradable N-compounds released by plant roots in their surrounding environment. Characteristic compounds in the root exudates are organic acids such as citrate, malate, fumarate, oxalate and acetate; carbohydrates such as glucose, xylose, fructose, maltose, sucrose, galactose, and ribose; inorganic compounds such as $\mathrm{CO}_{2}$, inorganic ions, protons and anions as consequence of the root metabolic activity; phyto-ormones, amino acids and small peptides. All these compounds are generally soluble and as such usually promptly accessible to the rhizosphere and rhizoplane microorganisms. Moreover, they may distribute at a longer distance from the rhizoplane than high-molecular weight compounds. Indeed, to be taken up by microorganisms, high-molecular weight compounds have to be firstly broken down in simpler, low weight molecular products. Moreover, plant capable of expressing favorable root exudate properties could accelerate sustainable agricultural production through improved access to soil unavailable nutrients.

Renella et al. (2007; 2011) provided an important contribution to understanding the effect of root exudates to the properties of rhizosphere hydrolytic enzymes. An incubation unit reproducing the rhizosphere environment was used as model root surface. It consisted in an experimental device with a cellulose round filter paper acting as an artificial root surface that allowed the release of compounds, simulating root exudates, and the sampling of soil layers at different distances from the cellulose filter surface. Experiments were performed with soils with different physical-chemical properties and low molecular weight organic compounds (LMWOC) as glucose, citrate, oxalate, glutamate (simulating C-rich substrates) (Renella et al., 2007), indoleacetic acid (IAA) and ethylene-polyamine (E) precursors, as representative of phytohormones (Renella et al., 2011). Acid and alkaline phosphatases, phosphodiesterase, $\beta$-glucosidase, $\beta$-galactosidase, urease, protease were investigated hydrolases.

The main results indicated that significant stimulation of rhizosphere enzymes occurred by LMWOC release depending on the compound released and the type of soil (sandy or clays soil), whereas stimulation in the 
bulk soil layer was not significant in any case (Renella et al., 2007).

IAA precursor significantly increased phosphatase, $\beta$-glucosidase, urease and protease activities while $\mathrm{E}$ precursor significantly increased phosphodiesterase, urease and protease activities. Both precursors probably acted as microbial metabolic activators rather than nutrient sources for microorganisms (Renella et al., 2011).

Results by Li et al. (2011) confirmed the important role played by ethylene in the modulation of $\mathrm{P}$ acquisition, through mobilization of organic $\mathrm{P}$ and up-regulation of root phosphatase activity and high-affinity phosphate transporters. An ethylene precursor (1-amino cyclopropane-1-carboxylic acid, ACC) and three ethylene synthesis antagonists (aminoethoxyvinylglycine AVG, cobalt, $\mathrm{Co}^{2+}$ ) were tested to determine the role of ethylene in response of plants to $\mathrm{P}$ deficiency (Li et al., 2011). The effect of the above compounds was investigated on $\mathrm{P}$ concentrations in roots and shoots of Medicago falcata seedlings grown in $\mathrm{P}$-sufficient and $\mathrm{P}$-deficient solution. $\mathrm{AVG}$ and $\mathrm{Co}^{2+}$ reversed the reduction in root $\mathrm{P}$ concentration, whereas ACC reduced root $\mathrm{P}$ concentration when seedlings were exposed to P-sufficient solution. P-deficient conditions considerably increased the activity of root acid phosphatase and expression of the encoding gene.

The promotion of enzyme production by the soil microbiota consequent to the addition of labile $\mathrm{C}$ and $\mathrm{N}$ substrates to soil was also demonstrated by Vong (2003), when examined the relationships between immobilized-S, microbial biomass-S and arylsulfatase activity in the rhizosphere soil from field-grown rape and barley plants. Indeed, rape rhizosphere soil showed a high activity of arylsulfatase per unit of microbial biomass-S, and organic acids were the most efficient substrates in increasing the production of the microbial enzyme.
Brzostek et al. (2013) showed that the exudation of carbon (C) by tree roots stimulates microbial activity and production of extracellular enzymes in the rhizosphere. To estimate a rhizosphere effect, rates of root exudation, microbial and extracellular enzyme activity, and nitrogen $(\mathrm{N})$ availability were measured. Rhizosphere and bulk soil was sampled as influenced by four temperate forest tree species, associated either to ectomycorrhizal (ECM) or arbuscular mycorrhizal (AM) fungi. The activities of protease, the chitinolytic enzyme n-acetyl glucosaminidase (NAG), acid phosphatase and two ligninolytic enzymes, phenol oxidase and peroxidase were measured. C-root exudation did not differ between species and although of small entity, it was sufficient to provide carbon to rhizosphere microbes. Extracellular enzyme activities were strongly stimulated in the rhizospheres of beech, while rhizosphere effects were fewer for hemlock and sugar maple and almost absent in ash. Effects on $\mathrm{N}$-cycling were also observed. It was concluded that $\mathrm{C}$ exudation has enhancing effects on both extracellular enzyme activity and nitrogen behavior (Brzostek et al., 2013).

Despite this experimental evidence, it remains, still unclear, how the below ground flux of $\mathrm{C}$ exactly affects the activity of microorganisms, exo-enzyme production and the depolymerization of $\mathrm{N}$-compounds.

\subsection{Priming effects by $\mathrm{CO}_{2}$ and exudate release}

As defined by Kuzyakov et al. (2000) priming effects are" strong short-term changes in the turnover of soil organic matter caused by comparatively moderate treatments of the soil". Usually, they are the consequence of addition of organic $\mathrm{C}$-substrates to the soil. As the turnover of soil organic matter is determined by variations in $\mathrm{CO}_{2}$ efflux or nitrogen mineralization rates, it is difficult to evaluate the origin of extra $\mathrm{CO}_{2}-\mathrm{C}$ (primed carbon) or $\mathrm{N}$ precisely. 
Moreover, processes such as an accelerated microbial turnover may contribute to the $\mathrm{CO}_{2}$ efflux rates or $\mathrm{N}$ mineralization variations. In fact, when the amount of labile substrates increases, they begin more available to microorganisms and, in turn, an increased enzyme production or activity may occur with a consequent increased co-metabolic decomposition of soil organic matter (Kuzyakov et al., 2000). Therefore, it can be stated that soil microorganisms are primarily or incidentally responsible of the real priming effects. When the process occurs in the rhizosphere it is called rhizosphere priming effect (RPE) (Haichar et al., 2014).

\subsection{Elevated $\mathrm{CO}_{2}$}

As schematized in Figure 2, elevated $\mathrm{CO}_{2}$ may induce RPE because it may produce qualitative and quantitative variations of plant $\mathrm{C}$ efflux into the rhizosphere. The main effect is an acceleration of metabolic. represented by respiration, and cometabolic, production of enzymes, activity.

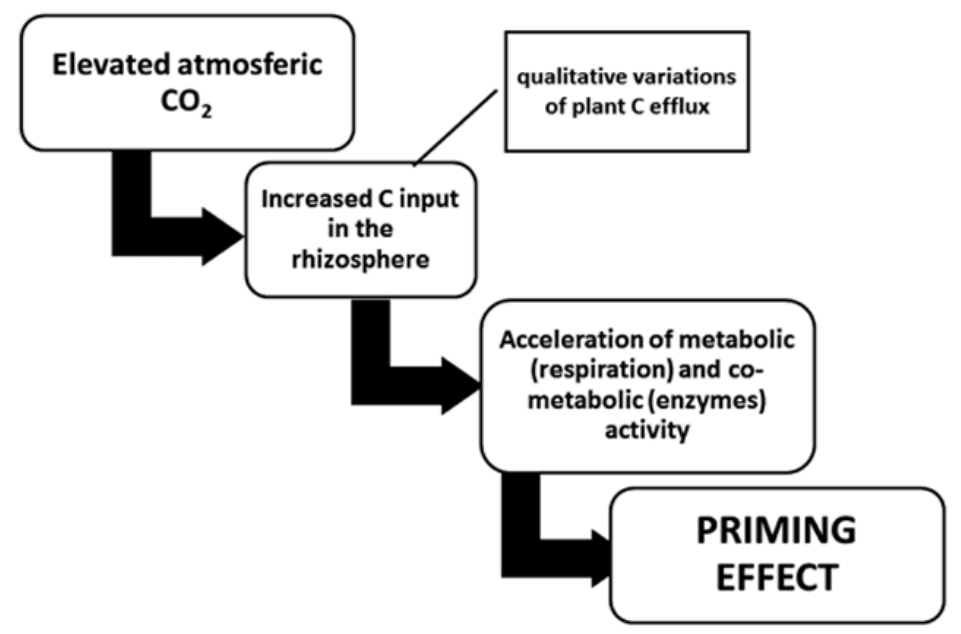

Figure 2. Events and causes leading to priming effects

Experiments performed on growth of Pinus densiflora seedling and enzyme activities in soil demonstrated that elevated $\mathrm{CO}_{2}$ concentrations produced different variations in soil chemistry and microbiology. Rhizosphere enzymatic activities, including $\beta$-glucosidase, $\mathrm{N}$-acetylglucode amidase and phosphatase increased whereas a decrease of soil moisture, nitrate concentration, and the concentration of soil phenolic compounds was measured (Kim et al., 2010).
Haase et al. (2008) found a complex response to elevated atmospheric $\mathrm{CO}_{2}$ associated to different $\mathrm{N}$ supply in the rhizosphere of Phaseolus vulgaris L. An increase of enzyme activities (xylosidase, cellobiosidase and leucine-aminopeptidase) was observed at an early stage of plant growth (12 days after sowing) by elevated $\mathrm{CO}_{2}$, as consequence of an increased release of low-molecular-weight compounds from apical root zones. By contrast, at later stages of plant growth (21 days after sowing), the activities of cited enzymes and of N-acetyl- $\beta$ - 
glucosaminidase and phosphatase decreased under elevated $\mathrm{CO}_{2}$. No effect on soil microbial community was found thus indicating that atmospheric $\mathrm{CO}_{2}$ altered enzyme activity and/or production rather than microorganism's quantity (Haase et al., 2008).

Different effects of elevated atmospheric $\mathrm{CO}_{2}$ at different nitrogen application treatments were also observed for $\beta$-glucosidase, invertase, urease, acid phosphatase and $\beta$-glucosaminidase activities under a rice/wheat rotation (Yuan et al., 2006). Invertase, xylanase, urease, protease, arylsulfatase, and alkaline phosphatase activities were measured in spring and summer when calcareous grassland was exposed to ambient and elevated $\mathrm{CO}_{2}$ concentrations (Ebersberger et al., 2003). Different responses were observed among enzymes, the two seasons and the $\mathrm{CO}_{2}$ concentrations. In spring, a general increase of enzyme activities occurred at elevated $\mathrm{CO}_{2}$. A correlation among increased enzyme activities, soil moisture and root biomass led to conclude that probably elevated $\mathrm{CO}_{2}$ will enhance below-ground $\mathrm{C}$ - and N-cycling in grasslands (Ebersberger et al., 2003).

\subsection{Exudates release}

Expression and repression of extracellular enzyme activity in the rhizosphere may be important to understand the relationship between enzyme activity and intensity/direction of RPE due to exudates.

The input of a substance inducing priming effect can activate the microbial synthesis of intracellular and extracellular enzymes, or can serve as energy source to microorganisms for the production of extracellular enzymes with the subsequent increase in the decomposition of native soil organic matter.

Microbial nutrition competition can be also responsible of the response of RPE to exudate release. For instance, reviewing data of literature, Fontaine et al. (2003) concluded that the priming effect results from the competition for energy and nutrient acquisition between the microorganisms specialized in the decomposition of fresh organic matter and those feeding on polymerized organic matter. In other words, addition of easily available organic C stimulates the growth of r-strategists and the successive growth of k-strategists is responsible of the degradation of recalcitrant organic matter. Obviously, intracellular and extracellular enzymes dominate the processes. Their synthesis, and consequently their activity, increases as result of the activation of soil microorganisms by the addition of the easily available organic C (Kuzyakov et al., 2000; Zhu et al., 2014).

\subsection{Different types of plants, soil management, temperature, drought, salinity}

Types and species of crops may influence rhizosphere enzyme activity and production. Usually, crops with higher root developments stimulate enzyme activities by the rhizosphere effect. Consequently, soil management influencing crop growth may also influence enzyme production at rhizosphere.

Highest acid phosphatase activity was measured in the rhizosphere of white lupin, followed by faba bean, field pea and wheat (Nuruzzaman et al., 2006). Moreover, this activity was higher in the rhizosphere of all species as compared with bulk soil and enhanced when citrate was present in the soil and no phosphorus fertilization occurred.

Arylsufatase activity was measured in the rhizosphere and roots of Sinapis album, Lolium perenne, Triticuma estivum and Brassica napus, grown on three different soils from a long-term field experiment (Knauff et al., 2003). Soils were supplemented with mineral fertilizer, compost and farmyard manure. The enzyme activity was highest in the rhizosphere of $B$. napus and T. aestivum, and lowest of $S$. album and 
L. perenne in compost-supplemented soils. Moreover, results obtained in roots of sterile-grown plants suggested that arylsulfatase activity derived from endophytic bacteria rather than higher plants (Knauff et al., 2003).

Eleven extracellular enzymes involved in $\mathrm{C}, \mathrm{N}, \mathrm{P}$, and $\mathrm{S}$ cycling differently responded to inorganic and organic fertilization in both the rhizosphere and bulk soil samples from a long-term (31-year) fertilizer experimental field at the wheat reproductive stage (Ai et al., 2012). In particular, six treatments were investigated: without fertilization, fertilizer $\mathrm{N}$, fertilizer $\mathrm{N}$ and $\mathrm{P}$, fertilizer $\mathrm{N}, \mathrm{P}$ and $\mathrm{K}$, organic manure, and organic manure plus fertilizer N, P and K. Inorganic fertilizers generally preserved or decreased several enzyme activities in the rhizosphere, but significantly increased them in the bulk soil. However, organic treatments enhanced most enzyme activities in both the rhizosphere and bulk soil. The abundance of bacteria, fungi and actinomycetes in the rhizosphere did not significantly differ between inorganic and organic treatments, whereas most significant changes occurred in the bulk soil. These results suggested that different fertilization regimes greater influenced the microbial community in the bulk soil than in the rhizosphere (Ai et al., 2012).

Temperature can also affect rhizosphere enzyme activities. For instance, the activity of phytase in the rhizosphere of four annual crops (cluster bean, moth bean, mung bean, pearl millet), three trees (neem, mopane, eucalyptus) and two grasses (dhaman, sewan), grown in an arid environment, was differently affected by either temperature or tillage (Yadav and Tarafdar, 2004). Phytase activity largely varied in different plant rhizospheres, and it was generally higher compared to fallow soils (control). The enzyme showed different temperature optimum in the range $25-35{ }^{\circ} \mathrm{C}$ with maximum values at $35^{\circ} \mathrm{C}$ and markedly decreases at or above $40^{\circ} \mathrm{C}$. Moreover, phytase activity was higher under no-tillage than tillage conditions in annual crops.

Drought is a climatic factor strictly associated with temperature, and as such, it can influence the activities of enzymes in soil and rhizosphere. However, no many results are available in literature on the effect of drought on the interactions of roots and microorganisms in the rhizosphere under different plant communities.

Sanaullah et al. (2011) studied how drought influenced the activity of xylanase, $\beta$-cellobiosidase and $\beta$-glucosidase (C-cycle), leucine-aminopeptidase (N-cycle), and chitinase (both $\mathrm{C}$ - and $\mathrm{N}$-cycles) in the rhizosphere of two grasses (Lolium perenne and Festuca arundinacea) and one legume (Medicago sativa), grown individually or in mixture under controlled laboratory conditions. Unplanted soil was the control. Drought strongly decreased enzyme activities in unplanted soil, whereas different results were obtained depending on the presence of cultures, particularly if under monoculture or mixtures of two or three cultures, and on the type of the enzyme. For instance, drought conditions highly increased leucineaminopeptidase activity under mixture and two out of three monocultures, suggesting an enhanced $\mathrm{N}$ demand. C-cycle enzymes generally decreased under drought with different trends if under mono or mixed cultures. Overall results suggested that both drought and plant species composition are the main factors influencing the response of rhizosphere enzymes to drought effect.

Further information was achieved by evaluating the influence of water stress on rhizosphere enzymes in drought and non-drought tolerant species. The activities of alkaline and acid phosphatase, protease, catalase and invertase were measured in the rhizosphere of two corn hybrids, Baidan 9 (drought tolerant) and Baidan 31 (non-drought tolerant) under water stress conditions (Song et al., 2012). The 
response of enzymes varied depending on the growth stages, but their activities generally increased in the rhizosphere of the drought-tolerant corn hybrid, except acid phosphatase. An enhanced exudation of organic acids (malic, lactic, acetic, succinic, citric and maleic acids) was associated to the increase of enzyme activities, indicating that both soil enzymes and rhizosphere exudates might participate in drought tolerance.

Linked to water stress is also salinity, mainly in semiarid and arid soils. Usually, soil enzyme activities decrease under saline conditions (Gianfreda and Bollag, 1996; Gianfreda and Ruggiero, 2006). In particular, when cotton was grown in saline, nonsaline and moderately saline soils, the activities of urease, protease, alkaline phosphomonoesterase and phosphodiesterase, galactosidase, glucosidase and fluorescein diacetate differently responded to salinity conditions and correlated to soil properties such as soil electrical conductivity, organic matter, $\mathrm{Cl}$, and $\mathrm{Na}$ contents (Egamberdieva et al., 2011). High levels of salinity generally inhibited the activity of all enzymes but at different percentages (up to $75 \%$ for fluorescein diacetate). No correlation was observed, however, between acid phosphomonoesterase, phosphodiesterase, and galactosidase and previous cited soil properties, although an increased salinity further decreased their activity levels.

Different factors may explain the response of soil enzymes to salinity conditions. Salinity may reduce microbial biomass and, in turn, a lower production of enzymes may occur. In addition, if enzymes are present as stable complexes with soil colloids (situation likely frequent in arid and semiarid soils), high levels of salts may destabilize the enzymatic complexes by dispersion of clays and enzyme denaturation may more easily occur. Finally, an increase of salt concentration may lead to the osmotic desiccation of microbial cells. Intracellular enzymes may be released and loose activity because of soil component denaturing processes. A salting-out effect of soluble salts on enzyme protein producing a decline in enzyme activity may be also hypothesized (Gianfreda and Bollag, 1996).

\section{Plants-microorganisms interactions}

As shown in Figure 1 and above discussed, the functional activity in the rhizosphere is greatly influenced by the interactions between plants, plant roots and microorganisms. Consequently, numerous studies have been devoted to elucidate such interaction and associated mechanisms.

As well explained by Haichar et al. (2014) "the root exudate composition reflects the contradictoryconcomitantly attractive and repulsive-behavior of plants towards soil microorganisms". Indeed, plants may release in their surrounding (rhizosphere) compounds that can act either to repel pathogens and invaders (antimicrobial, insecticide and nematicide substance) or to attract phytobeneficial soil microorganisms (nutrients such as carbon sources). Moreover, as reported above, root exudates may have a RPE by regulating both carbon and nitrogen cycles. Finally, the establishment of 'plant-microorganisms' interactions is controlled by particular molecules (hormones, phenolic acids, specific chelators etc.) having a special function in the plant signaling process.

Under iron (Fe) deficiency conditions, grasses produced specific chelators, such as phytosiderophores and siderophores (Marschner et al., 2011). These molecules facilitate $\mathrm{Fe}$ complexation by enhancing its diffusion to the cell surface. In the rhizosphere, competition between microorganisms and plants occurs for both iron and phosphorous demand, being microorganisms more competitive for their capacity to break down plant-chelators and plants more able to 
counteract direct competition with microorganisms, because of their spatial and temporal adaptability in releasing various amounts and different compositions of exudates (Marschner et al., 2011). By a model of the roots-microorganisms interactions at the root axis, presenting both its advantages and limitations, Marschner et al. (2011) suggested some mechanisms like increasing turnover of microbial biomass or enhanced nutrient uptake capacity of mature root zones, which enhance plant competitiveness. Their analysis can be useful not only for obtaining plant genotypes with improved efficacy in nutrient acquisition but also for understanding phosphorous and iron biogeochemistry and helping in fertilization practices (Marschner et al., 2011).

Much information on the contribution of plant roots and microorganisms to the whole rhizosphere activity is provided by experiments based on mycorrhiza, inocula of plant growth promoting rhizobacteria (PGPR), inocula of genetically modified microorganisms, transgenic plants.

In the present issue, various papers address some of these topics in particular the role of mycorrhiza and microorganisms acting as plant growth promoters (like PGPR) (see Azcón-Aguilar and Barea; Barea; Jorquera et al. in this Special Issue), and therefore they will be not discussed in detail in the present paper. Few results dealing with the effects of mycorrhiza and PGPR on the response of rhizosphere enzymes will be just commented.

The activities of esterase, phosphatase, trehalase and chitinase were measured in the rhizosphere of maize plants, to test the influence of a phytostimulators (Azospirillum) or biological control agents of fungi (Pseudomonas and Trichoderma) upon mycorrhizal colonization in plants inoculated with Glomus mosseae, Glomus deserticola and natural AMF from the test soil (Vázquez et al., 2000). All enzyme activities were increased at different percentages, depending on the inoculant and the AMF. The highest increase (444\%) was observed for trehalase by $G$. deserticola inoculum. These variations confirm the role of enzymes as useful indexes of changes occurring in the microbial functioning in soil. They seem to suggest that modifications of the microbial community structure and ecology occurred. Modifications were confirmed by the qualitative changes observed in the bacterial population depending on the inoculant combination involved.

Tarafdar and Marschner (1994) early observed the beneficial effect of mycorrhizal infection on rhizosphere enzyme activity. They studied phosphatase activity in the rhizosphere of arbuscular mycorrhizal wheat supplied with inorganic and organic phosphorus. In the proximity of root, both acid and alkaline phosphatase activities were slightly enhanced by mycorrhizal (Glomus mosseae) infection, with acid phosphatase much higher than alkaline one. As already mentioned, the presence of $P$ supply stimulated the efficient use of phytate-P by phosphatase of mycorrhizal hyphae.

Recently, Welc et al. (2014) investigated the abundance, distribution and functions of soil fungi in alpine ecosystems. The authors tried to link the fungal community structure with soil enzymatic activities in the rhizospheres of several plants associating with mycorrhizal fungi (arbuscular, ecto- and ericoid) and growing along a soil developmental gradient on the fore field of an alpine glacier. Studies were concentrated on four alpine plant species (Salix helvetica, Agrostis gigantea, Leucanthemopsis alpina and Rhododendron ferrugineum) and in bare soil. The identity of fungal community structure at roots level was assessed by both staining visualization and DNA extraction and determination. The activities of acid phosphatase, chitinase, protease, $\alpha$-glucosidase, $\beta$ glucosidase, xylosidase, and sulfatase were measured by fluorogenic assays. As expected, rhizosphere 
enzyme activities were influenced by soil age, plant species and associated mycorrhizal fungi. In general, soil age did not change or increased rhizosphere enzyme activities. Species-specific increases of rhizosphere enzymes were observed. Chitinase and $\alpha$-glucosidase activities were significantly higher in the rhizosphere of S. helvetica than in most other plants, while phosphatase, xylosidase and $\beta$-glucosidase activities were elevated in the rhizosphere of $A$. gigantea and $\alpha$-glucosidase and sulfatase in Rhododendron ferrugineum (Welc et al., 2014). Overall results indicated that a clear link exists between soil fungal communities and soil enzyme activities, although experimental limitations are still present to establish a straight forward relationship between the observed effects (e.g. increased enzyme activity) and activity of mycorrhizal fungi and/or roots (Welc et al., 2014).

As many times highlighted in this paper, solubilization of poorly available phosphorus pools in the rhizosphere is a crucial process to allow a safe growth of plant and to improve crop yields. Therefore, phosphate-solubilizing microorganisms, including bacteria and fungi, may have important beneficial effects on plant growth and metabolism. One of the enzymes contributing to P-solubilization is phytase and phytase-producing bacteria have attracted the attention of several researchers as potential tools to add to soil and support plant growth (see Jorquera et al., 2008; Menezes-Blackburn et al., 2013). Phytases are powerful enzymes because are able to degrade not only fresh organic residues but also to release inorganic P from soil organic matter. Additionally, these enzymes may preserve their activity even if complexed with soil colloids (Menezes-Blackburn et al., 2011; 2013). Obviously, phosphatases may also serve as efficient P-solubilizing enzymes and phosphatase-producing microorganisms have been widely studied and applied to improve soil phosphorus utilization.

Yadav and Tarafdar (2003) isolated seven efficient phytase- and phosphatase-producing fungi, belonging to Aspergillus, Emmericella and Penicillium genera. Fungi released more extracellular phytase than phosphatase but all were able to hydrolyze at high percentages phytin and glycerophosphate, used as organic P substrate models.

Among bacteria, strains from the genera Pseudomonas, Bacillus and Rhizobium are very powerful phosphate solubilizers (Rodríguez and Fraga, 1999). The bacteria produced organic acids and mainly acid phosphatases that played a main role in the mineralization of organic P in soil. Genes encoding the enzyme were isolated and characterized.

Several investigations have been and are performed on the genetic manipulation of microorganisms, including phosphate-solubilizing bacteria, to improve their capabilities and enhance their effect on plant growth.

Naseby and Lynch $(1997 ; 1998)$ and Naseby et al. (1998) obtained important and interesting results by inoculating the seeds of different plants (wheat, sugar beet and pea), with Pseudomonas fluorescens, a wild type producing the antifungal 2,4-diacetylphloroglucinol (DAPG) and marked with a lacZY gene cassette. Investigations with functionally modified Pseudomonas strains with repressed production of DAPG were also performed for comparison (Figure 3). The activities of several enzymes, including alkaline phosphatase, acid phosphatase, urease, phosphodiesterase, arylsulfatase, chitobiosidase, $\beta$-galactosidase, $\beta$-glucosidase, $\mathrm{N}$-acetylglucosaminidase, were measured. Increases, decreases or no effects on enzyme activity levels occurred depending on the plant species, and on the type of inoculated microorganism. Comparison among results obtained with DAPG + and DAPG- 
strains led to conclude that the impact of various genetically modified Pseudomonas on the rhizosphere populations and functions depended on the nature of the genetic modification.

\section{Genetically Modified Microorganisms}

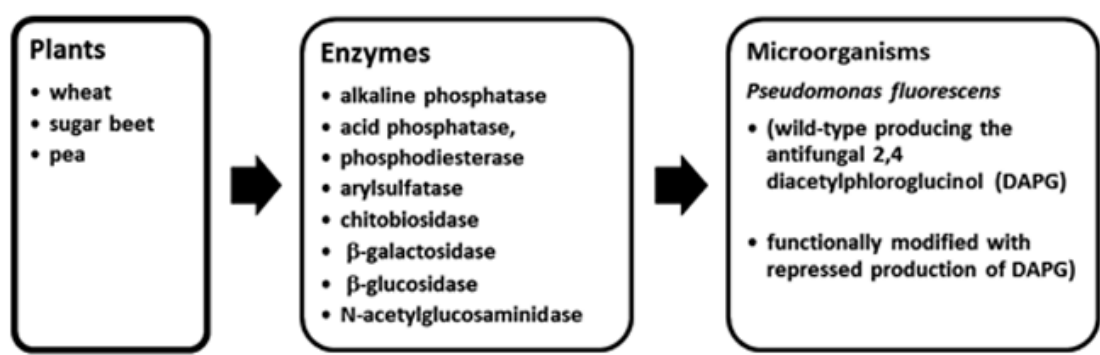

Increases, decreases or no effects on enzyme activity levels occurred depending on the plant species, and the type of inoculed microorganism

The impact of various genetically modified Pseudomonas on the rhizosphere populations and functions depended on the nature of the genetic modification

Figure 3. Summary of experiments made with genetically modified Pseudomonas fluorescens (from Naseby and Lynch, 1997; 1998; Naseby et al., 1998)

Transgenic plants obtained by the insertion of specific bacterial or fungal genes coding for particularly efficient enzymes is a possible mean for improving rhizosphere activity. Experiments carried out on transgenic plants such as Arabidopsis thaliana, Nicotianatabacum, T. subterraneum, containing phytase genes from Aspergillus and Bacillus released phytases with higher activity versus various organic $\mathrm{P}$ sources or with changed specificity (use of phytate as the sole P source) (Egamberdieva et al., 2011; George et al., 2005). When the plant-derived extracellular phytase was added to soil, the enzyme was, however, rapidly adsorbed on the soil matrix and lost its activity. The phenomenon was less pronounced in the rhizosphere soil indicating that the rhizosphere environment may preserve much more phytase activity in solution. (George et al., 2005).

However, possible negative effects on microbial community could occur in the rhizosphere of transgenic plants, whose biochemistry has been manipulated. George et al. (2009) demonstrated that the expression of phytase in transgenic Nicotianatabacum had little or no impact on the microbial community structure as compared with control plant lines, thus demonstrating that "the microbial community in the rhizosphere appears to be resistant to the impacts of singlegene changes in plants designed to alter rhizosphere biochemistry and nutrient cycling".

Beneficial effects on $\mathrm{P}$ acquisition of white clover (Trifolium repens L.) were found when a phytase 
gene (MtPHY1) and a purple acid phosphatase gene (MtPAP1), both isolated from the model legume Medicago truncatula, were introduced in the plant by Agrobacterium-mediated transformation (Ma et al., 2009). Transgenic plants accumulated much higher amounts of total P (up to 2.6-fold after 80 days of growth) than the control, thus showing their increased abilities of utilizing organic phosphorus in response to P deficiency.

Similar results were obtained with transgenic Arabidopsis (Mudge et al., 2003). Aspergillus niger phytase gene, active in the root epidermis only when the plant is grown on medium containing low phosphate concentrations, was inserted in the Arabidopsis by means of a specific phosphate transporter promoter. Transgenic Arabidopsis efficiently secreted phytase and grew on medium containing phytate as a sole $P$ source, thus confirming the efficacy of transgenic technology to improving crop P uptake and nutrition (Mudge et al., 2003).

\subsection{Rhizosphere enzymes and functional diversity}

Previous findings clearly demonstrate that soil enzyme activities and mainly rhizosphere enzymes may well serve as indicators of microbial functional diversity (Caldwell, 2005).

Total soil include genetic, taxonomic and functional diversity (Zak et al., 1994). Therefore, functional diversity is one of the elements contributing to the overall soil biodiversity and in turn, it depends on the genetic variability within a taxon, the environmental effects on gene expression and the ecological interactions among tax. For Insam et al. (1989) microbial functional diversity represents "the sum of the ecological processes developed by the organisms of a community and it can be expressed through species or important groups to maintain several functions in the soil, while the genetic one represents gene and genotype variations". As such, it can provide a more practical and ecologically relevant measure of microbial diversity (Marinari et al., 2014).

While physiological or genetic diversity of soil microorganisms is a measure of the microbial potential, functional diversity of soil enzymes gives a measure of actual activity deriving from that potential (Caldwell, 2005). As reported above, phenomena occurring in the rhizosphere may interfere and greatly affect the functional diversity of the microbial community living in it. Indeed, rhizosphere microbial community and composition may change depending on the amount, type and composition of root exudates. Moreover, root exudates will be different depending on the plant species that will influence and stimulate the abundance and survival of particular groups of microorganisms. The composition of these microbial groups will determine the potential for enzyme synthesis and finally root exudates will modify the actual rate of enzyme production and their activity. It can be concluded that a greater functional diversity of microbial community in the rhizosphere will result in elevated activities of many enzymes (see review by Marinari et al., 2014).

It appears evident that these statements are worthwhile and functional diversity is determined, provided rhizosphere enzyme activities (involved in as many as possible nutrient's cycles) could be easily and clearly estimated and possibly combined in diversity indexes or microbial indexes.

\section{Rhizosphere enzymes and pollutants}

The interactions occurring between microorganisms and enzymes increase the potentiality of the rhizosphere in the transformation and/or degradation of polluting compounds, with results in the restoration of polluted environments. Indeed, plants and microorganisms synergically interact to each other 
with beneficial, mutual effects of microbial and plant on a more efficient removal of pollutants from the contaminated soil.

The "rhizosphere effect" for pollutant transformation was well described by Siciliano and Germida (1998) "Microorganisms may reduce the phytotoxicity of contaminants to the point where plants can grow in adverse soil conditions, thereby stimulating the degradation of other, non-phytotoxic contaminants" and by Walton et al. (1994) "Plants and microbes have co-evolved a mutually-beneficial strategy for dealing with phytotoxicity, where microorganisms benefit from the plant exudates while the plants benefit from the ability of microorganisms to break down toxic chemicals".

Even degradative enzymes released by plant roots in their surrounding environment may give an important contribution to the degradation of pollutants occurring in the rhizosphere. They are usually ecto-enzymes (wall-associated enzymes) and provide to partially transforming substances in products more easily uptaken by plant roots or rhizosphere microorganisms. Plant oxidoreductases and hydrolases released in the rhizosphere of different plant species efficiently transformed phenols, polychlorinated biphenyls (PCBs), polycyclic aromatic hydrocarbons (PAHs) and estrogenic chemicals (see Gianfreda et al., 2006; Gianfreda and Rao, 2004)

Muratova et al. (2009 a, b) demonstrated that an increased production of phenol oxidase peroxidase, and tyrosinase activities occurred in root exudates of the phyto remediating plant Sorghum bicolor (L.) Moench when exposed to increased phenanthrene concentrations. Indeed, the activities of these enzymes were progressive as the soil phenanthrene concentration increased, thus showing an active role of enzymes released by root exudation. The degradation of various PAHs and derivatives was enhanced by the presence of mediators such as ABTS or DL-
DOPA and an increased population of phenanthrenedegrading microorganisms in the rhizosphere was also observed. The results clearly showed a positive response in the degradation of PAHs and derivatives by plants growing in contaminated soils.

Rhizosphere enzymes were also involved in plants subjected to environmental $\mathrm{Hg}$ stress ( $\mathrm{Li}$ et al., 2013). Indeed, greater superoxide dismutase (SOD), catalase (CAT) and ascorbate peroxidase (APX) activities were measured in the wheat plants grown in an $\mathrm{Hg}$ highly polluted soil. The plants positively adapted to environmental $\mathrm{Hg}$ stress by three important mechanisms involved in the metal uptake/tolerance: rhizosphere acidification, enhancement of DOC production and greater antioxidant enzyme activities. An interesting role of rhizosphere enzymes in the degradation of pollutants is linked to transgenic plants. Indeed, genes involved in metabolism, uptake, or transport of specific pollutants can be overexpressed in plants that become capable of expressing enzymes efficient in the rhizodegradation of highly recalcitrant compounds like PAHs, PCBs etc...(Abhilash et al., 2009). A list of transgenic plants and rhizosphere enzymes involved in the degradation of a large range of xenobiotic compounds is provided by Abhilash et al. (2009) and therefore will not be reported here.Transgenic plants and their expressed enzymes present many advantages. Pollutants should not been taken up by plants to be degraded and the secreted enzymes can degrade the pollutants in the rhizospheric zone. Additional rhizosphere effects may enhance pollutant degradation. Indeed, microbial density, diversity and/or metabolic activity increase by the plant root exudates, mucigel and root lysates and physical and chemical properties of the contaminated soil can be increased by plants and by the contact between the root-associated microorganisms and the soil contaminants. 
PGPR have been demonstrated to be useful not only to promoting plant growth by colonizing the plant root and to assisting plants to uptake nutrients from the environment or preventing plant diseases, but also for remediating contaminated soils in association with plants (Zhuang et al., 2006). Table 1 reports examples of PGPR associated to plants, transformed pollutants and the role of PGPR. It appears evident the potentialities of PGPR in rhizoremediation of polluting substances. As concluded by Zhuang et al. (2006) "The recent researches of PGPR on the remediation of contaminated soils show a brilliant prospect for the successive studies. For example, the combined use of PGPR and specific contaminantdegrading bacteria can successfully remove complex contaminants ".

Table 1. PGPR, associated plant, transformed pollutants and role of PGPR (modified from Zhuang et al., 2007).

\begin{tabular}{|l|l|l|l|}
\hline \multicolumn{1}{|c|}{ Pollutant } & \multicolumn{2}{c|}{ Racteria } & Associated Plant \\
\hline Organic pollutants & \multicolumn{2}{|c|}{ PGPR } & Wheat \\
\hline Crude oil & Azozpirillium lipoferum & Promoted development of root system & Tall fescue \\
\hline PAHs & Azozpirillium brasilense & Increased plant tolerance to PAHs & $\begin{array}{l}\text { Alfalfa } \\
\text { Arobidopsis }\end{array}$ \\
\hline PCBs & $\begin{array}{l}\text { Pseudomonas fluorescens } \\
\text { Pseudomonas putida }\end{array}$ & $\begin{array}{l}\text { Increased metabolization } \\
\text { Utilization of plant secondary metabolites }\end{array}$ & Wheat \\
\hline Trichloroethylene & Pseudomonas fluorescens & Degradation by toluene o-monooxygenase & Brassica juncea \\
\hline Heavy metals & \multicolumn{5}{|l|}{$\begin{array}{l}\text { Astragalus sinicus } \\
\text { Lead, zinc }\end{array}$} & $\begin{array}{l}\text { Mesorhizobiumhuakuii } \\
\text { Pseudomnas fluorescens }\end{array}$ & $\begin{array}{l}\text { Increased ability of plant cells to bind Cd } \\
\text { Sequestration of the metal from the solution }\end{array}$ \\
\hline Cadmium & Bacillus subtilis & Facilitated nickel accumulation & Brassica juncea \\
\hline Nickel
\end{tabular}

\section{Methods for studying rhizoshere enzymes}

The rhizosphere studies have been challenged by the lack of satisfying methods for obtaining sufficient soil samples for subsequent laboratorial analysis. Several methodological approaches are now available to study the impact of plant roots on their surrounding soil, the consequent properties and to elucidate the related mechanisms (Neumann et al., 2009).

Most common procedures consist in slicing soil in multiple segments, and determining rhizosphere properties, including enzyme activities, in each of them. However, this method suffers from a number of experimental problems that may invalidate the obtained results leading to over- or underestimation of rhizosphere properties. For instance, the amount of soil sample is usually very small for chemical determinations of nutrients and much more for enzyme activity assays, and the extent to which roots affect these parameters.

Another method is to build up special tools like rhizoboxes. Various types of rhizoboxes have been prepared and used. The rhizosphere is divided into several thin sections in such a way that the chemical and biochemical properties can be analyzed at increasing distances from the root surface. However, 
regardless of many methodological approaches available for studying processes and interactions in the rhizosphere, adequate methods to test the relevance of these findings under real field conditions or even on the scale of ecosystems are still lacking (Neumann et al., 2009).

Recently, a new in situ technique, called soil zymography, has provided further insights in the distribution and quantification of microbial- and root-derived enzyme activities in the rhizosphere of plants (Spohn et al., 2013; Spohn and Kuzyakov, 2013; 2014). In particular, the technique was applied to study phosphatase activities in the rhizosphere of Lupinus albus L and Hordeum Vulgare and their dependence on $\mathrm{P}$ availability and $\mathrm{C}$ allocation.

Zymography is a non-destructive in situ method for the exploration of two-dimensional distributions of enzyme activities with a high spatial resolution. The usual protocol for the soil in situ zymography was adapted from standard zymography assays for protease and amylase activity detection in electrophoresis gels (Spohn et al., 2013). The protease zymographyis based on the observation that Coomassie Brilliant Blue stains proteins, but not proteolytic products such as small peptides and amino acids. Moreover, the coupling with ${ }^{14} \mathrm{C}$ imaging and use of fluorescent substrates enhanced the efficiency of the method (Spohn and Kuzyakov, 2013).

As shown in Figure 4, soil zymography allowed to obtaining hotspots of acid and alkaline phosphatase activity in the rhizosphere of Lupinus albus L (Spohn and Kuzyakov, 2013). It was demonstrated that acid phosphatase activity (produced by booth roots and microorganisms) was closely associated with roots, whereas alkaline phosphatase activity (produced only by microorganisms) was more widely distributed, leading to a 2.5-times larger area of high activity of alkaline than of acid phosphatase in soil. Results also indicated a spatial separation of various organisms able to mineralize organic phosphorus. Moreover, it was possible to reveal that $\mathrm{P}$ fertilization strongly decreased alkaline phosphatase activity, but had no effect on acid phosphatase activity (Figure 4), thus indicating a greater effect of $\mathrm{P}$ changes on alkaline phosphatase than L. albus and acid phosphatase producing microorganisms. The authors concluded that evidently, different ecophysiological groups of organisms capable of mineralizing organic $P$ exist and their spatial differentiation possible reduces a potential competition between them (Spohn and Kuzyakov, 2013).

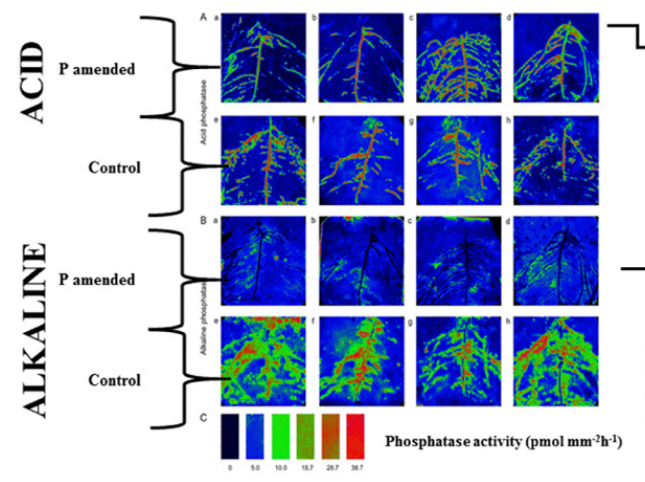

No effect of $P$ fertilization

Acid phosphatase activity (produced by roots and microorganisms) was closely associated with roots

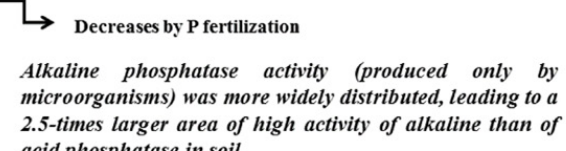
2.5-times larger area of high activity of alkaline than of acid phosphatase in soil.

Figure 4. Hotspots of acid and alkaline phosphatase activity in the rhizosphere of Lupinus albus L depending on P availability and C allocation by zymoghapy (as modified from (Spohn and Kuzyakov, 2013) 
Further investigations identified hotspots of phosphatase, cellulase and chitinase activities in the rhizosphere of living L. Polyphyllus roots prior to shoot cutting and dead/dying roots 10, 20 and 30 days after shoot cutting (Spohn and Kuzyakov, 2014). The analysis also indicated that hotspots of enzyme activity in soil strongly depended on carbon inputs such as rhizo deposits and root detritus.

All these results confirm soil zymographyas a very efficient technology. It allowed highlighting a spatial differentiation of plant and microbial extracellular enzyme activities, to identify micro-hotspots of enzyme activity up to several $\mathrm{cm}$ away from living and dying roots, and to identify that some of them most likely were caused by microorganisms (Spohn and Kuzyakov, 2014).

\subsection{Stoichiometry studies}

Recently, Bell et al. (2014) studied the relation between rhizosphere enzymes and soil, plants and microbes by utilizing the stoichiometry approach developed by Sinsabaugh and co-workers (2008; 2009; 2011; 2012).

In different ecosystems, Sinsabaugh and Follstad Shah (2011; 2012) and Sinsabaugh et al., (2008; 2009) related, with stoichiometric evaluation, the activities of several enzymes, representative of soil microbial functions, to different soil properties and functions such as global biomass composition, nutrient dynamics, soil organic matter storage, energy and nutrient availability in the environment, microbial nutrient assimilation, growth and expression efficiency. From overall results, the authors concluded that a similar stoichiometry can be derived between the more common measured soil enzymatic activities and all microbial communities (Sinsabaugh and Follstad Shah, 2011; 2012; Sinsabaugh et al., 2008;2009).
Bell et al. (2014) hypothesized that "soil nutrient and microbial stoichiometry would differ among plant species and be correlated within plant rhizospheres" They assayed several properties and enzyme activities in eight different intact species-specific plants (belonging to functional groups of legume, C3, C4 plants, and forb) and in non-vegetated soil as control, in a semiarid grassland in Wyoming, USA. In particular, they measured $\mathrm{C}: \mathrm{N}: \mathrm{P}$ ratios in plant tissues and $\mathrm{C}: \mathrm{N}: \mathrm{P}$ ratios, microbial biomass $\mathrm{C}: \mathrm{N}$ and soil enzyme $\mathrm{C}: \mathrm{N}: \mathrm{P}$ nutrient acquisition activities in plant rhizospheres. Enzymes tested were those related to $\mathrm{C}$-rich substrates $(\beta-1,4$-glucosidase, b-cellobiosidase. $\alpha$-glucosidase, $\quad \beta$-xylosidase), $\mathrm{N}$-rich substrates $(\beta-1,4-\mathrm{N}$-acetylglucosaminidase, leucine aminopeptidase) and P-rich substrates (phosphatase). Their main results can be summarized as follows: a) few of the plant species' rhizospheres demonstrated distinct stoichiometric properties from other plant species and non-vegetated soil; b) below-ground nutrient stoichiometry (as reflected in nutrient ratios of soil extracts, enzymes, and microbial biomass) significantly differed among plant species; c) in several cases, microbial, soil, and plant stoichiometry components significantly correlated within plant tissue stoichiometry; d) enzyme, soil, and plant $\mathrm{C}: \mathrm{N}$ stoichiometry strongly correlated with relative $\mathrm{C}: \mathrm{P}$ and $\mathrm{N}: \mathrm{P}$ stoichiometry components (i.e. relative enzyme, microbial biomass, soil, and plant stoichiometry). These results led to conclude that "Assessing the ecological stoichiometry among plant species' rhizospheres is a high-resolution tool useful for linking ecosystem function and plant community composition, microbial community traits, soil nutrient availability and potential nutrient feedbacks". Moreover, "By identifying how rhizospheres differ among plant species, we can better assess how plantmicrobial interactions associated with ecosystem- 
level processes may be influenced by plant community shifts" (Bell et al., 2014).

\section{Conclusive remarks}

The findings briefly commented in this paper clearly indicate the importance of rhizosphere enzymes in the eco-physiological life of soil. They govern and drive many important processes fundamental to plant and microorganism survival.

Being produced in a restricted soil area their production and activity may be affected by several factors, more or less influencing their final function. An important role is played by plant exudates. They may have greatly effect on expression and repression of extracellular enzyme activity in the rhizosphere. The knowledge of the dynamic of these two processes may be helpful to understand the relationship between enzyme activity and intensity/direction of priming effect due to plant exudates.

Moreover, higher activity of several enzymes can be interpreted as a greater functional diversity of the microbial community in the rhizosphere. Insights in this topic may derive by rhizosphere stoichiometry. It is a unique approach to evaluating plant-microbial interactions within a single ecosystem, which integrates information related to soil ecology and plant species' abundances. Finally, rhizosphere enzymes may have great potentialities in soil remediation.

As early claimed by Lynch (1994) the lack of reliable, accurate and universal methodologies has hampered for many years the study of the population biology of rhizosphere. Nowadays, several advanced and sophisticated methodologies are available to reveal the origins, location and activities of enzymes in soil. One of them (soil zymography) has been briefly illustrated, but other innovative approaches (such as functional gene probes, nano-sensors, metagenomics, proteomics and metaproteomics, metabolomics) "could overcome many of obstacles still impeding satisfactory and reasonable resolution to not yet resolved and long-standing questions about several aspects regarding rhizosphere enzymes and their role in the mechanisms of biogeochemical processes and the controls on microbial diversity" (Rao et al., 2014).

\section{Acknowledgments}

This work was partially supported by the Chilean Research Program "Atracción de Capital Humano Avanzado del Extranjero Modalidad Estadías Cortas (MEC), año 2013”.

\section{References}

Abhilash, P.C., Jamil, S., Singh, N. 2009. Transgenic plants for enhanced biodegradation and phytoremediation oforganic xenobiotics. Biotechnol. Adv. 27, 474-488.

Ai, C., Liang, G., Sun J., Wang X., Zhou W. 2012. Response of ectracellular enzyme activities and microbial community in both the rhizosphere and bulk soil to long-term fertilization practices in a fluvo-aquic soil. Geoderma. 173-174, 330-33.

Bell, C, Carrillo, Y., Boot, C.M., Rocca, J.D., Pendall, E., Wallenstein, M.D. 2014. Rhizosphere stoichiometry: Are C: N: P ratios of plants, soils, and enzymes conserved at the plant specieslevel?. New Phytolog. 201, 505-517.

Brzostek, E.R., Greco, A., Drake, J.E., Finzi A.C. 2013. Root carbon inputs to the rhizosphere stimulate extracellular enzyme activity and increase nitrogen availability in temperate forest soils. Biogeochemistry. 115, 65-76.

Caldwell, B.A. 2005. Enzyme activities as a component of soil biodiversity: A review. Pedobiologia. 49, 637-644. 
Chroma, L,Mackovam M, Kucerovam, P., Der Wiesche, C., Burkhard, J., Macek, T. 2002. Enzymes in plant metabolism of PCBs and PAHs. Acta Biotechnol. 22, 35-41.

Dick, R.P. 1994. Soil enzymes activities as indicators of soil quality. In: J.W. Doran, D.C. Coleman, D.F. Bezdicek, B.A. Stewart (eds). Defining soil quality for a sustainable environment. SSSA Special Publication: Madison, Wl, USA, vol. 35, pp 107-124.

Dick, R.P. 1997. Soil enzyme activities as integrative indicators of soil health. In: C.E. Pankhurst, B.M. Doube, V.V.S.R. Gupta (eds.), Biological indicators of soil health. CAB International, Wallingford, pp. 121-156.

Egamberdieva, D., Renella, G., Wirth, S., Islam, R. 2011. Enzyme Activities in the Rhizosphere of Plants. In G. Shukla, A. Varma (ed). , Soil Enzymology. Soil Biology. Vol. 22, Springer Verlag, pp. 149-165.

Ebersberger, D., Niklaus, P.A, Kandeler,E. 2003.Long term $\mathrm{CO}_{2}$ enrichment stimulates $\mathrm{N}$-mineralisation and enzyme activities in calcareous grassland. Soil Biol. Biochem. 35, 965-972.

Fontaine, S., Mariotti, A., Abbadie, L. 2003. The priming effect of organic matter: a question of microbial competition?. Soil Biol. Biochem.35, 837-843.

Gartner, T.B., Treseder, K.K., Malcolm, G.M., Sinsabaugh, R.L. 2012. Extracellular enzyme activity in the mycorrhizospheres of a boreal fire chronosequence. Pedobiologia. 55, 121-127.

George, T.S., Gregory, P.J., Wood, M., Read, D., Buresh, R.J. 2002. Phosphatase activity and organic acids in the rhizosphere of potential agroforestry species and maize. Soil Biol. Biochem. 34, 1487-1494.
George, T.S., Gregory, P.J., Hocking, P., George, T.S., 2008. Variation in root-associated phosphatase activities in wheat contributes to the utilization of organic $\mathrm{P}$ substrates in vitro, but does not explain differences in the P-nutrition of plants when grown in soils. Environ. Experim. Botany. 64, 239-249.

George, T.S., Richardson, A.E., Simpson, R.J. 2005. Behaviour of plant-derived extracellular phytase upon addition to soil. Soil Biol. Biochem. 37, 977-988.

George, T.S., Richardson, A.E. , Li, S.S., Gregory, P.J., Daniell, T.J. 2009. Extracellular release of a heterologous phytase from roots of transgenic plants: does manipulation of rhizosphere biochemistry impact microbial community structure?. FEMS Microbiol. Ecol. 70, 433-445.

Gianfreda, L., Bollag, J.M. 1996. Influence of natural and anthropogenic factors on enzyme activity in soil. In G. Stotzky, J.-M .Bollag, (eds), Soil biochemistry. Marcel Dekker vol 9, New York, pp. 123-194.

Gianfreda, L., Rao M.A. 2004. Potential of extra cellular enzymes in remediation of polluted soils: a review. Enz. Microb. Technol. 35, 339-354.

Gianfreda, L., Ruggiero, P. 2006. Enzyme activities in soil. In P.Nannipieri,K.Smalla (eds) Nucleic acids and proteins in soil. Series Soil Biology, Vol. 8. Springer-Verlag, Berlin, Germany, p. 257-311.

Gianfreda, L., Mora, M.L., Diez, M.C. 2006. Restoration of polluted soils by means of microbial and enzymatic processes. J. Soil Sci. Plant Nut. 6, 20-40.

Gramss, G., Voigt, K.D., Kirsche, B. 1999. Degradation of polycyclic aromatics hydrocarbons with three to seven aromatic rings by higher fungi in sterile and unsterile soils. Biodegradation. 10, 51-62. 
Haase, S., Philippot, L., Neumann, G., Marhan, S., Kandeler, E. 2008. Local response of bacterial densities and enzyme activities to elevated atmospheric $\mathrm{CO}_{2}$ and different $\mathrm{N}$ supply in the rhizosphere of Phaseolus vulgaris L. Soil Biol. Biochem. 40, 1225-1234.

Haichar, F.Z., Santaella, C., Heulin, T., Achouak, W. 2014. Root exudates mediated interactions belowground. Soil Biol. Biochem. 77, 69-80.

Harvey, P.J., Xiang, M., Palmer, J.M. 2002. Extracellular enzymes in the rhizosphere. Proc. Inter-Cost Workshop on soil-microbe-root interactions: maximising phytoremediation/ bioremediation. Grainau, Germany, 23-25.

Hinsinger, P., Plassard, C., Jaillard, B. 2006. Rhizosphere: A new frontier for soil biogeochemistry, J. Geochem. Explor. 88, 210213.

Hinsinger, P., Bravin, M.N., Devau, N., Gérard, F., Le Cadre, E., Jaillard, B. 2008. Soil-RootMicrobe Interactions in the Rhizosphere - A Key to Understanding and Predicting Nutrient Bioavailability to Plants. J. Soil Sci. Plant Nutr. 8, 39-47.

Insam, H., Parkinson, D., Domsch, K.H. 1989. Influence of macroclimate on soil microbial biomass. Soil Biol. Biochem. 21, 211-221.

Jorquera, M., Martinez, O., Maruyama, F., Marschner, P., Mora, M.L. 2008. Current and Future Biotechnological Applications of Bacterial Phytases and Phytase-Producing Bacteria. Microbes Environ. 23, 182-191.

Kim, S., Jung, S., Kang, H., Lee, I. 2010. Effects of elevated $\mathrm{CO}_{2}$ on growth of Pinus densiflora seedling and enzyme activities in soil. J. Ecol. Field Biol. 33, 133-139.
Knauff, U., Schulz, M., W. Heinrich, S. 2003. Arylsufatase activity in the rhizosphere and roots of different crop species, Europ. J. Agron. 19, 215-223.

Kumar, S, Chaudhuri, S., Maiti, S.K. 2011. Phosphatase activity in natural and mined soil - A review. Indian J. Environ. Prot. 31, 955-962.

Kuzyakov, Y., Friedel, J.K., Stahr, K., 2000. Review of mechanisms and quantification of priming effects. Soil Biol. Biochem. 32, 1485-1498.

Li, Y., Sun, H., Li, H., Yang, L., Ye, B., Wang, W. 2013. Dynamic changes of rhizosphere properties and antioxidant enzyme responses of wheat plants (Triticum aestivum L.) Chemosphere. 93, 972977.

Li, Y.S., Gao, Y., Tian, Q.Y., Shi, F.L., Li, L.H., Zhang, W.H. 2011. Stimulation of root acid phosphatase by phosphorus deficiency is regulated by ethylene in Medicago falcate. Environ. Experim. Botany. 71, 114-120.

Ma, X.F., Wright, E., Ge, Y., Bell, J., Xi, Y., Bouton, J. H., Wang, Z.Y. 2009. Improving phosphorus acquisition of white clover (Trifolium repens L.) by transgenic expression of plant-derived phytase and acid phosphatase genes. Plant Sci. 176, 479488.

Marinari, S., Moscatelli, C., Grego, S. 2014. Enzymes at Plant-Soil Interface. In: L. Gianfreda, M.A. Rao, (eds.) Enzymes in agricultural sciences OMICS eBooks Group, pp. 94-109.

Marschner, P., Crowley, D., Rengel, Z. 2011. Rhizosphere interactions between microorganisms and plants govern iron and phosphorus acquisition along the root axis : model and research methods. Soil Biol. Biochem. 43, 883-894. 
Maseko, S.T., Dakora, F.D. 2013. Rhizosphere acid and alkaline phosphatase activity as a marker of $\mathrm{Pb}$ nutrition in nodulated Cyclopia and Aspalathus species in the Cape fynbos of South Africa. South African J. Bot. 89, 289-295.

Menezes-Blackburn, D., Jorquera, M.A., Greiner, R., Gianfreda, L., Mora, M.L. 2013. Phytases and Phytase-Labile Organic Phosphorus in Manures and Soils. Critic. Rev. Environm. Sci. Technol. 43, 916-954.

Menezes-Blackburn, D., Jorquera, M.A., Gianfreda, L., Mora M.L., Greiner, R., Garrido, E. 2011. Activity stabilization of Aspergillus niger and Escherichia coli phytases immobilized on allophanic synthetic compounds and montmorillonite nanoclays. Biores. Technol. 102, 9360-9367.

Mudge, S.R., Smith, F.W., Richardson, A.E. 2003. Root-specific and phosphate-regulated expression of phytase under the control of a phosphate transporter promoter enables Arabidopsis to grow on phytate as a sole P source. Plant Sci. 165, 871878.

Muratova, A., Pozdnyakova, N., Golubev, S., Wittenmayer, L., Makarov, O., Merbach, W., Turkovskaya, O. 2009. Oxidoreductase activity of sorghum root exudates in a phenanthrenecontaminated environment. Chemosphere. 74, 1031-1036.

Muratova, A., Golubev, S., Wittenmayer, L., Dmitrieva, T., Bondarenkova, A., Hirche, F., Merbach, W., Turkovskaya, O. 2009. Effect of the polycyclic aromatic hydrocarbon phenanthrene on root exudation of Sorghum bicolor (L.) Moench. Environm. Experim. Bot. 66, 514-521.

Naseby, D.C., Linch, J.M. 1997. Rhizosphere soil enzymes as indicators of perturbations caused by enzyme substrate addition and inoculation of a genetically modified strain of Pseudomonas
Fluorescens on wheat seed. Soil Biol. Biochem. 29, 1353-1362.

Naseby, D.C., Linch, J.M. 1998. Impact of wildtype and genetically modified Pseudomonas Fluorescens on soil enzyme activities and microbial population structure in the rhizosphere of pea. Mol. Ecol. 7, 617-625.

Naseby, D.C., Linch, J.M. 2002. Enzymes and microorganisms in the rhizosphere. In R.G. Burns R.P. Dick (eds) Enzymes in the environment. Activity, ecology and applications. Marcel Dekker, New York, pp. 109-123.

Naseby, D.C., Moënne-Loccoz, J.P., O'Gara, F., Lynch, J.M. 1998. Soil enzyme activities in the rizosphere of field-grown sugar beet inoculated with the biocontrol agent Pseudomonas Fluorescens F113. Biol. Fertil. Soils. 27, 39-43.

Neumann, G., George, T.S., Plassard, C. 2009. Strategies and methods for studying the rhizosphere-the plant science toolbox. Plant Soil. 321, 431-456.

Nuruzzaman, M., Lambers, H., Bolland, M.D.A. 2006. Distribution of carboxylates ad acid phosphatase and depletion of different phosphorus fractions in the rhizosphere of a cereal and three grain legumes. Plant Soil. 281, 109-120.

Raaijmakers, J.M., Paulitz, T.C., Steinberg, C., Alabouvette, C., Moënne-Loccoz, Y. 2009. The rhizosphere: a playground and battlefield for soilborne pathogens and beneficial microorganisms. Plant Soil. 321, 341-361.

Rao, M.A., Scelza, R., Gianfreda, L. 2014. Soil Enzymes. In: L. Gianfreda, M.A. Rao (eds.) Enzymes in agricultural sciences OMICS eBooks Group, pp. 10-43.

Renella, G., Landi, L., Valori, F., Nannipieri, P. 2007. Microbial and hydrolase activity after release of low molecular weight organic compounds by a 
model root surface in a clayey and a sandy soil Appl. Soil Ecol. 36, 124-129.

Renella, G., Landi, L., Garcia Mina, J.M., Giagnoni, L. Nannipieri, P. 2011. Microbial and hydrolase activity after release of indoleacetic acid and ethylene-polyamine precursors by a model root surface. Appl. Soil Ecol. 47, 106-110.

Rodríguez,. H., Fraga, R., 1999. Phosphate solubilizing bacteria and their role in plant growth promotion, Biotechnol. Adv. 17, 319-339.

Sanaullah, M., Blagodatskaya, E., Chabbi, A., Rumpel, C., Kuzyakov, Y. 2011. Drought effects on microbial biomass and enzyme activities in the rhizosphere of grasses depend on plant community composition. Appl. Soil Ecol. 48, 38-44.

Siciliano, S.D., Germida, J.J. 1998. Mechanism of phytoremediation: biochemical and ecological interactions between plants and bacteria. Environm. Rev. 6, 65-79.

Sinsabaugh, R, Follstad Shah, J.J. 2011. Ecoenzymatic stoichiometry of recalcitrant organic matter decomposition: the growth rate hypothesis in reverse. Biogeochemistry. 102, 31-43.

Sinsabaugh, R, Follstad Shah, J.J. 2012. Ecoenzymatic stoichiometry and ecological theory. Ann. Rev. Ecol. Evol. Syst. 43, 313-343.

Sinsabaugh, R., Hill, B., Shah, J. 2009. Ecoenzymatic stoichiometry of microbial organic nutrient acquisition in soil and sediment. Nature. 462, 795-799.

Sinsabaugh, R., Lauber, C., Weintraub, M., Ahmed, B., Allison, S., Crenshaw, C., Contosta, A.R., Cusack, D., Frey, S., Gallo, M.E., Gartner, T.B., Hobbie, S.E., Holland, K., Keeler, B.L., Powers, J.S., Stursova, M., Takacs-Vesbach, C., Waldrop, M.P., Wallenstein, M.D., Zak, D.R., Zeglin, L.H. 2008. Stoichiometry of soil enzyme activity at global scale. Ecol. Lett. 11, 1252-1264.
Song, F., Han, X., Zhu, X., Herbert, S.J. 2012. Response to water stress of soil enzymes and root exudates from drought and non-drought tolerant corn hybrids at different growth stages. Can. J. Soil Sci. 92, 501-507.

Spohn, M., Carminati, A., Kuzyakov, Y. 2013. Soil zymography - A novel in situ method for mapping distribution of enzyme activity in soil. Soil Biol. Biochem. 58, 275-280.

Spohn, M., Kuzyakov, Y. 2013. Distribution of microbial- and root-derived phosphatase activities in the rhizosphere depending on $\mathrm{P}$ availability and $\mathrm{C}$ allocation - Coupling soil zymography with ${ }^{14} \mathrm{C}$ imaging. Soil Biol. Biochem. 67, 106-113.

Spohn, M., Kuzyakov, Y. 2014. Spatial and temporal dynamics of hotspots of enzyme activity in soil as affected by living and dead roots: a soil zymography analysis. Plant Soil. 379, 67-77.

Tarafdar, J.C., Marschner, H. 1994. Phosphatase activity in the rhizosphere and hyposphere of VA mycorrhizal wheat supplied with inorganic and organic phosphorus Soil Biol. Biochem. 26, 387-395.

Vázquez, M., César, S., Azcón, R., Barea, J.M. 2000. Interactions between arbuscularmycorrhizal fungi and other microbial inoculants (Azospirillum, Pseudomonas, Trichoderma) and their effects on microbial population and enzyme activities in the rhizosphere of maize plants. Appl. Soil Ecol. 15, 261-272.

Vong, P.-C., Dedourge, O., Lasserre-Joulin, F., Guckert, A. 2003. Immobilized- S, microbial biomass-S and soil arylsulfatase activity in the rhizosphere soil of rape and barley as affected by labile substrate $\mathrm{C}$ and $\mathrm{N}$ additions. Soil Biol. Biochem. 35, 1651-1661. 
Walton, B.T., Hoylman, A.M., Perez, M.M., Anderson, T.A., Johnson, T.R., Guthrie, E.A., Christmas, R.F. 1994. Rizhospheremicrobical community as a plant defense against toxic substances in soils. In: T.A. Anderson, J.R.Coats. (eds.) Bioremediation through rizhosphere technology American Schemical Society: Washington D.C., pp. 82-92.

Welc, M., Frossard, E., Egli, S, Bünemann, E.K., Jansa, J. 2014. Rhizosphere fungal assemblages and soil enzymatic activities in a 110-years alpine chronosequence. Soil Biol. Biochem. 74, 21-30.

Wu, Q.S., He, X.H., Zou, Y.N., He, K.P. Sun, Y.H. 2012. Spatial distribution of glomalin-related soil protein and its relationships with root mycorrhization, soil aggregates, carbohydrates, activity of protease and $\beta$-glucosidase in the rhizosphere of Citrus unshiu. Soil Biol. Biochem. $45,181-183$.

Yadav, B.K., Tarafdar, J.C. 2003. Phytase and phosphatase producing fungi in arid and semi-arid soils and their efficiency in hydrolyzing different organic P compounds. Soil Biol. Biochem. 35, 745-751.
Yadav, B.K., Tarafdar, J.C, 2004. Phytase activity in the rhizosphere of crops, trees and grasses under arid environment. J. Arid Environm. 58, 285-293.

Yuan, X., Lin, X., Chu, H., Yin, R., Zhang, H., Hu, J., Zhu, J. 2006. Effects of elevated atmospheric $\mathrm{CO}_{2}$ on soil enzyme activities at different nitrogen application treatments. Acta Ecol. Sinica. 26, 4853.

Zak, J.C., Willig, M.R., Moorhead, D.L., Wildman, H.G. 1994. Functional diversity of microbial communities: A quantitative approach. Soil Biol. Biochem. 26, 1101-1108.

Zhu, B., Gutknecht, J.L.M., Herman, D.J., Keck, D.C., Firestone, M.K., Cheng W. 2014. Rhizosphere priming effects on soil carbon and nitrogen mineralization. Soil Biol. Biochem. 76, 183-192.

Zhuang, X., Chen, J., Shim, H., Bai, Z. 2007. New advances in plant growth-promoting rhizobacteria for bioremediation. Environm. Intern. 33, 406-413. 